Bangladesh J. Plant Taxon. 26(1): 83-95, 2019 (June)

(C) 2019 Bangladesh Association of Plant Taxonomists

\title{
ETHNOMEDICINAL PLANTS FOR PREVENTION OF CARDIOVASCULAR DISEASES IN BANGLADESH
}

\author{
Mohammad Zashim Uddin ${ }^{1}$, Atiya Begum Rifat, Farhana Yesmin Mitu \\ AND TAHMINA HaQue \\ Department of Botany, University of Dhaka, Dhaka 1000, Bangladesh
}

Keywords: Ethnomedicinal plants; Prevention; Cardiovascular diseases; Bangladesh.

\begin{abstract}
Cardiovascular diseases (CVD) are the major causes of death globally. The treatment of CVD by using modern medicines is very expensive. The present article mainly focuses the ethnomedicinal plants used by the local people for the prevention of cardiovascular diseases in Bangladesh. Information on the ethnomedicinal uses of plants was collected using semi-structured interviews with key informants during the year of 2017 and 2018. Group discussion with local people was also conducted for the promotion of data collection. A total of 41 medicinal plant species was recorded for the prevention of cardiovascular diseases. These species belong to 30 families. The most frequently used medicinal plant species for the prevention of cardiovascular diseases were Terminalia arjuna (Roxb. ex DC.) Wight \& Arn., Terminalia bellirica (Gaertn.) Roxb., Terminalia chebula Retz., Allium sativum L., Tamarindus indica L. and Alternanthera sessilis (L.) R. Br. ex Roem. Informant consensus factor (Fic) has been calculated to determine the agreement of local people in the use of medicinal plants for the CVD. Among the ailments categories high Fic value was found in case of antioxidant followed by heartache, high blood pressure and blood purifier. Comparing with previous research Hylocereus undatus (Haw.) Briton and Rose, Alternanthera paronychioides Klotzsch ex Koch and Lactuca sativa L. were seem to be newly reported medicinal plants for the prevention of cardiovascular diseases in Bangladesh. The plant species with high citation, Fic and Fl values can be subjected to phytochemical investigation to find new class of active compounds for the treatment of cardiovascular diseases. The findings of the present study are very preliminary. Further long term studies are needed to validate the ethnomedicinal plants used by the local people for the prevention of cardiovascular diseases in Bangladesh.
\end{abstract}

\section{Introduction}

Cardiovascular diseases (CVD) refer to any disorders of the heart and blood vessels. The most common ones are disorder of the heart muscle, strokes, heart failure and those caused by high blood pressure (Olorunnisola et al., 2011). Worldwide, CVD is assuming an increasing role as a major cause of morbidity and mortality (Krisela, 2007). It is estimated at approximately 1.6 million deaths per annum worldwide (WHO, 2003). Between 1990 and 2020, the proportion of deaths from CVD is projected to increase from 28.9 to $36.3 \%$ (Gowri et al., 2011). Moreover, in terms of number of years of life lost, CVD is expected to jump in ranking from the fourth to first, while as a cause of premature death and disability, it will rise from fifth to first (Hennekens, 2000). The predisposing factors to CVD include cigarette smoking, elevated cholesterol, hypertension, obesity, physical inactivity and diabetes (Olorunnisola et al., 2011). According to the INTERHEART study, Bangladeshis had the highest prevalence of CVD risk factor among five South Asian countries with the prevalence of self-reported history of hypertension (14.3\%),

\footnotetext{
${ }^{1}$ Corresponding author, Email: zashim01@ gmail.com
} 
abdominal obesity (43.3\%), current and former smoking (59.9\%), and the lowest prevalence for regular physical activity $(1.3 \%)$ and daily intake of fruits and vegetables $(8.6 \%)$ (Joshi et al., 2007). In Bangladesh, 99.6\% male and 97.9\% females are exposed to at least one of the established risks of CVD and at risk of CVD at a younger age (below 40 years in men) (El-Saharty et al., 2013). The expected high incidence of the diseases, couple with high cost of modern pharmaceuticals and healthcare remedies, makes it all important to search for safe, effective and cheaper remedies from natural world. Before the discovery of modern medicines, many plants have been used by human in the management, treatment and the related complications of CVD. In Bangladesh a number of plants are reputed to possess cardio protective properties, resulting in their use by traditional healer for treatment of chest complaints, high cholesterol, high and low blood pressure and general heart problems. Plants may serve as the alternative sources for the development of new anticoagulant agents due to their biological activities. There is compelling scientific evidences demonstrating that the consumption of dietary anticoagulants or phytochemicals with anticoagulant properties can ultimately reduce or eliminate the risks of thromboembolic diseases (Kumar et al., 2011; Lee et al., 2012; Manicam et al., 2010). Currently, ethnomedicinal knowledge of plants has been eroding at alarming rate from the nature before proper documentation and evaluation. In order to protect such knowledge, documentation of ethnomedicinal plants is already started in Bangladesh. A number of articles published in this field included Mia and Haque (1988); Hassan and Khan (1986, 1996); Alam (1992); Alam et al. (1996); Uddin et al. (2001, 2006, 2012, 2017), Khan et al. (2002), Ghani (2003), Uddin et al. (2004), Yusuf and Uddin (2006); Yosuf (2006); Yusuf et al. (2009), Uddin and Roy (2007); Roy et al. (2008); Emily et al. (2010); Uddin (2013), Haque et al. (2014); Uddin et al. (2015a,b) and Haque et al. (2017). These articles listed a good number of medicinal plants of particular community or particular diseases or particular areas of Bangladesh. But there is no record of ethnomedicinal plant species useful for CVD management in Bangladesh. In order to document and validate ethnomedicinal plant species for CVD management in Bangladesh, an attempt was undertaken to achieve the following objectives: (a) to record, integrate and document all scattered traditional healthcare knowledge on ethnomedicinal plants for CVD management in Bangladesh, (b) to determine ethno-medically potential and culturally important and most cited plant species using statistical models, (c) to validate the folk knowledge of ethnomedicinal plants with thrombolytic agents.

\section{Materials and Methods}

Bangladesh is located in between $20^{\circ} 34^{\prime}$ to $26^{\circ} 38^{\prime} \mathrm{N}$ and $88^{\circ} 01^{\prime}$ to $92^{\circ} 41^{\prime} \mathrm{E}$ and total area is 147,570 sq. $\mathrm{km}$. The country is bounded by India to the West, North, East, by Myanmar to the South-East corner and By the Bay of Bangle to the South. Bangladesh ornamented by different forest types including hill forest, plain land sal forest, mangrove forest, fresh water swamp forest and homestead vegetations. Among the forest types native flora is very diverse due to geomorphological variations. Once Professor MS Khan estimated that the country may have 5000 angiosperm plant species. Very recently, the plant taxonomist compiled 3611 species from existing literature. Among them, more than 1000 plant species have been used by the local people as medicines. Bangladesh is the also dwelling place for a good number of ethnic communities. These communities have their own cultural tradition and heritage in their social life. For the primary health care they have been used native plant species.

Seven sampling sites have been selected for the data collection in Bangladesh. These are Thakurgaon, Dinajpur, Sirajgonj, Dhaka, Brahmanbaria, Feni and Bhola. The sampling sites have been visited during the year of 2017 and 2018. Visit duration for each site was lasted for 4-5 days. The data on medicinal uses of plants were recorded through semi-structured interviews, key 
informant discussions and also with the help of herbal practitioners (Alexiades, 1996). Field interview, plant interview and group discussion with local people were also conducted for the promotion of data collection. During the field survey, information on uses of plants to treat human, parts used, modes of preparation and administration was collected. The vernacular names have been collected with the help of local people whenever available. A total of 166 local informants including $66 \%$ males and $34 \%$ females were interviewed during the ethnobotanical survey. The local informants were housewives, herbalist, farmers, craftsmen, shopkeepers, teachers and also students. The informants were ranged within 21-70 years old. Voucher specimens for each medicinal plant species were collected and processed using standard herbarium techniques (Hyland, 1972). Identification of plant species have been done by the experts in both field and laboratory. In case of confusion in identity, standard literature was consulted and the relevant voucher specimens available at Dhaka University Salar Khan Herbarium (DUSH) were also compared. All voucher specimens were deposited at DUSH.

Factor of informant consensus (Fic), Fidelity level (Fl) and Citation frequency was calculated using bio statistical formulas. Factor of informant consensus (Fic) was calculated applying the following equation: Fic $=\mathrm{N}_{\mathrm{ur}}-\mathrm{N}_{\mathrm{taxa}} / \mathrm{N}_{\mathrm{ur}}-1$, Where $\mathrm{N}_{\mathrm{ur}}$ is the number of use reports in each category, $\mathrm{N}_{\text {taxa }}$ is the number of species in each category (Trotter and Logan, 1986; Heinrich et al., 1998). Citation frequency was calculated using the following formula: frequency of citation for a particular species $=$ (Number of citations for that particular species/ Number of all citations for all species) x 100 (Uddin et al., 2017). The Fidelity level, was calculated for the most frequently reported medicinal plant species as: $\mathrm{Fl}(\%)=(\mathrm{Np} / \mathrm{N}) \times 100$; Where, $\mathrm{Np}=$ number of informants that claim a use of a plant species to treat a particular disease; $\mathrm{N}=$ number of informants that use the plants as a medicine to treat any given disease (Friedman et al., 1986).

\section{Results and Discussion}

The present ethnobotanical survey recorded a total of 41 medicinal plants belonging to 30 families that were acquired by conducting 166 interviews for the treatment of cardiovascular diseases with 70 formularies from different district of Bangladesh (Table 1).

According to the habit diversity of recorded medicinal plant, 56\% was tree, $34 \%$ was herb, $5 \%$ was shrub and 5\% was climber (Fig.1). Leaves are the most commonly used part for medicinal plants or for the preparation of traditional medicine (Fig. 2). Similar trend of using leaves for medicinal use has also been reported from other studies from Bangladesh (Uddin et al., 2012; Biswas et al., 2010). According the citation frequency of all medicinal plants, the most frequently used plants were Terminalia arjuna (Roxb. ex DC.) Wight \& Arn., Terminalia bellirica (Gaertn.) Roxb., Terminalia chebula Retz., Allium sativum L., Tamarindus indica L. and Alternanthera sessilis (L.) R. Br. ex Roem.

In the present study 41 medicinal plant species have been found for the treatment of cardiac diseases. Medicinal plant from the families were found high number of species belong to Combretaceae, Ceasalpiniaceae and Apocyanaceae. The most cited species used to treat such ailments are Terminalia aurjuna, Terminalia bellirica, Alternanthera sessilis, Rauvolfia serpentina ,Tamarindus indica, Allium sativum, Zingiber officinale and Achyranthes aspera. To calculate the Factor of informant consensus (Fic) values total ailments were categorized into four groups viz: heartache, antioxidant, blood purifier and high blood pressure. The average Fic value for all ailment categories obtained was 0.78 . Such value indicated that maximum people in the study area were well informed about the medicinal knowledge of plants. Among the four categories antioxidant group attained the highest Fic values $(0.82)$ followed by heartache, high blood pressure (0.79) and blood purifier $(0.74$, Table 2$)$. 


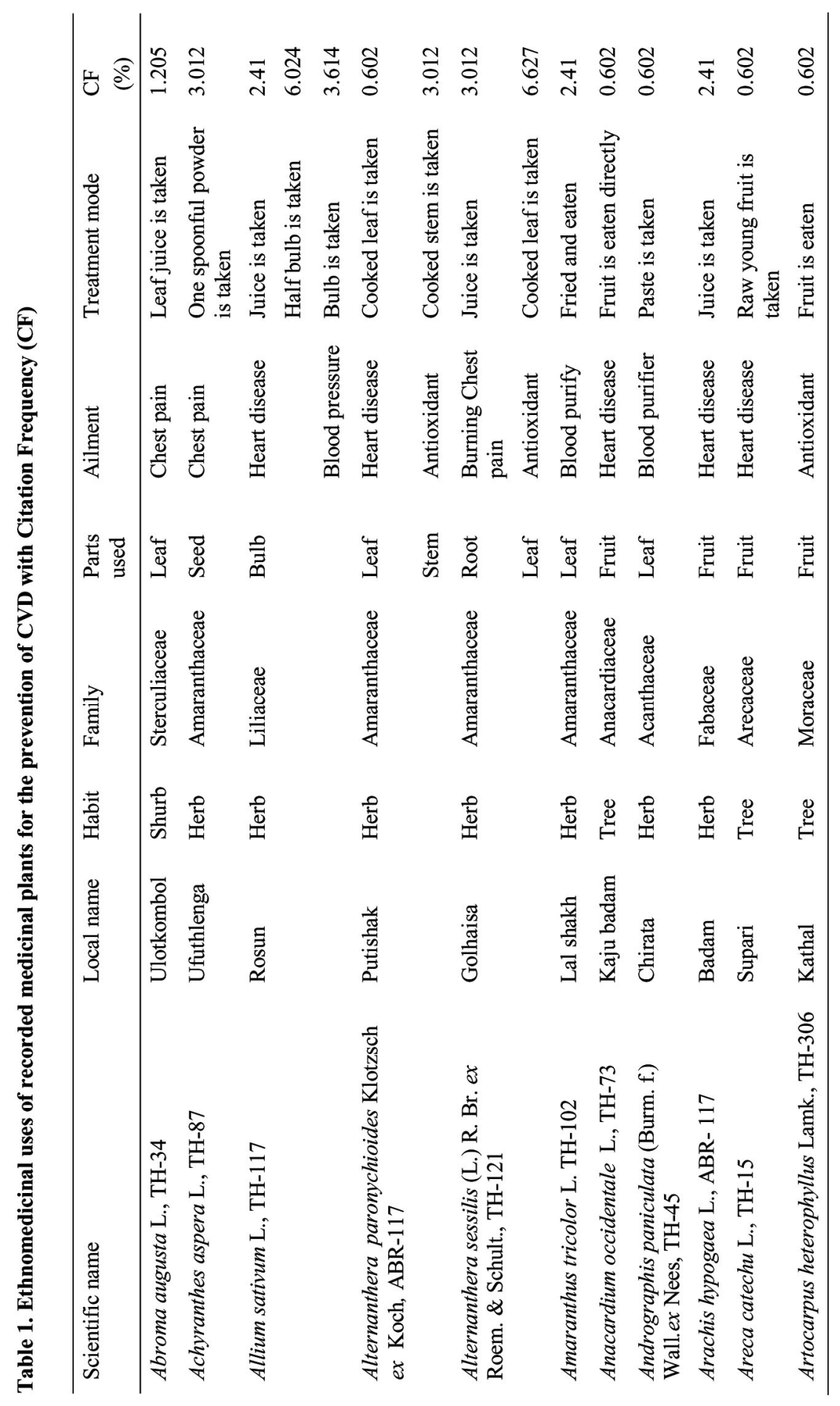




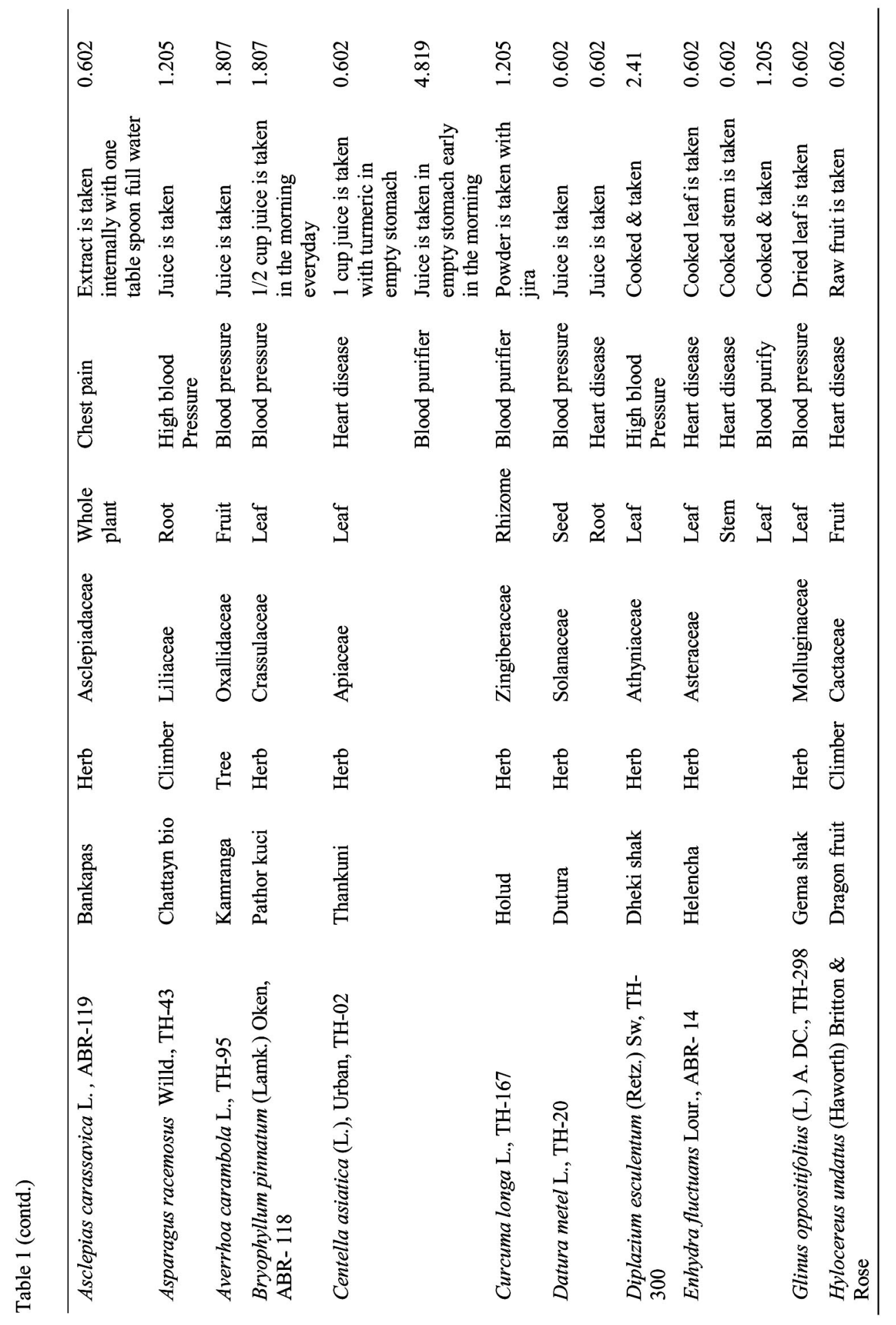




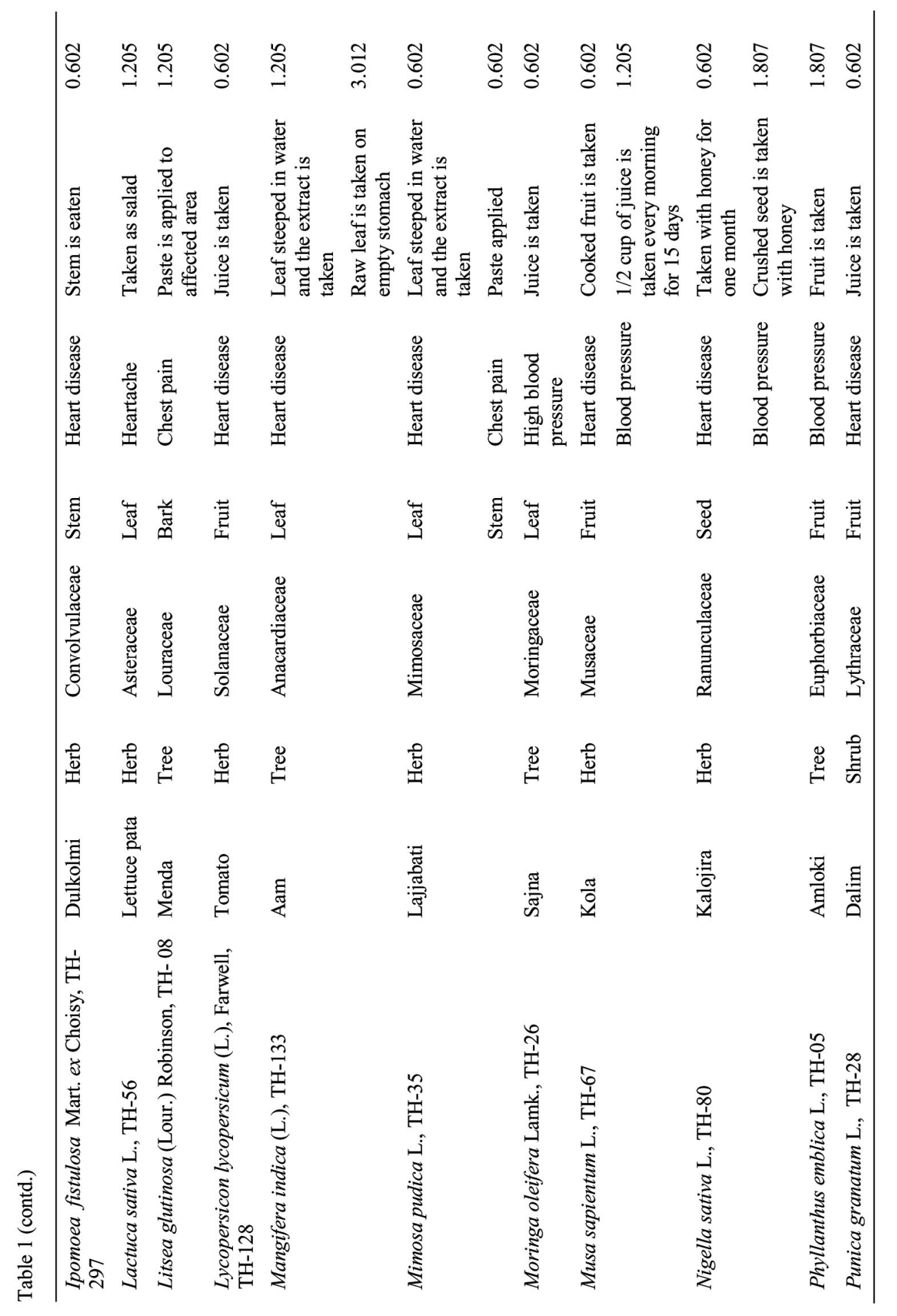




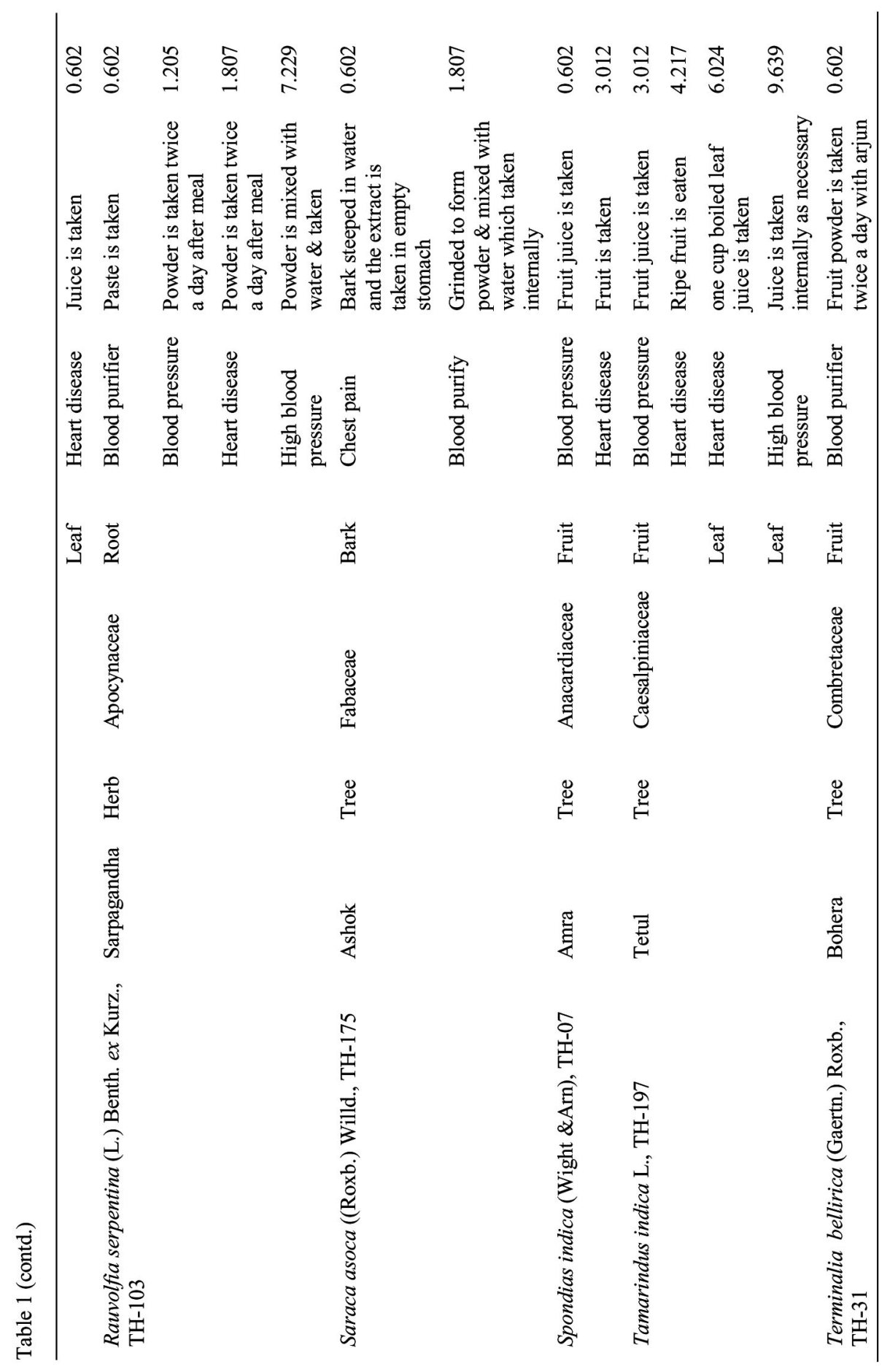




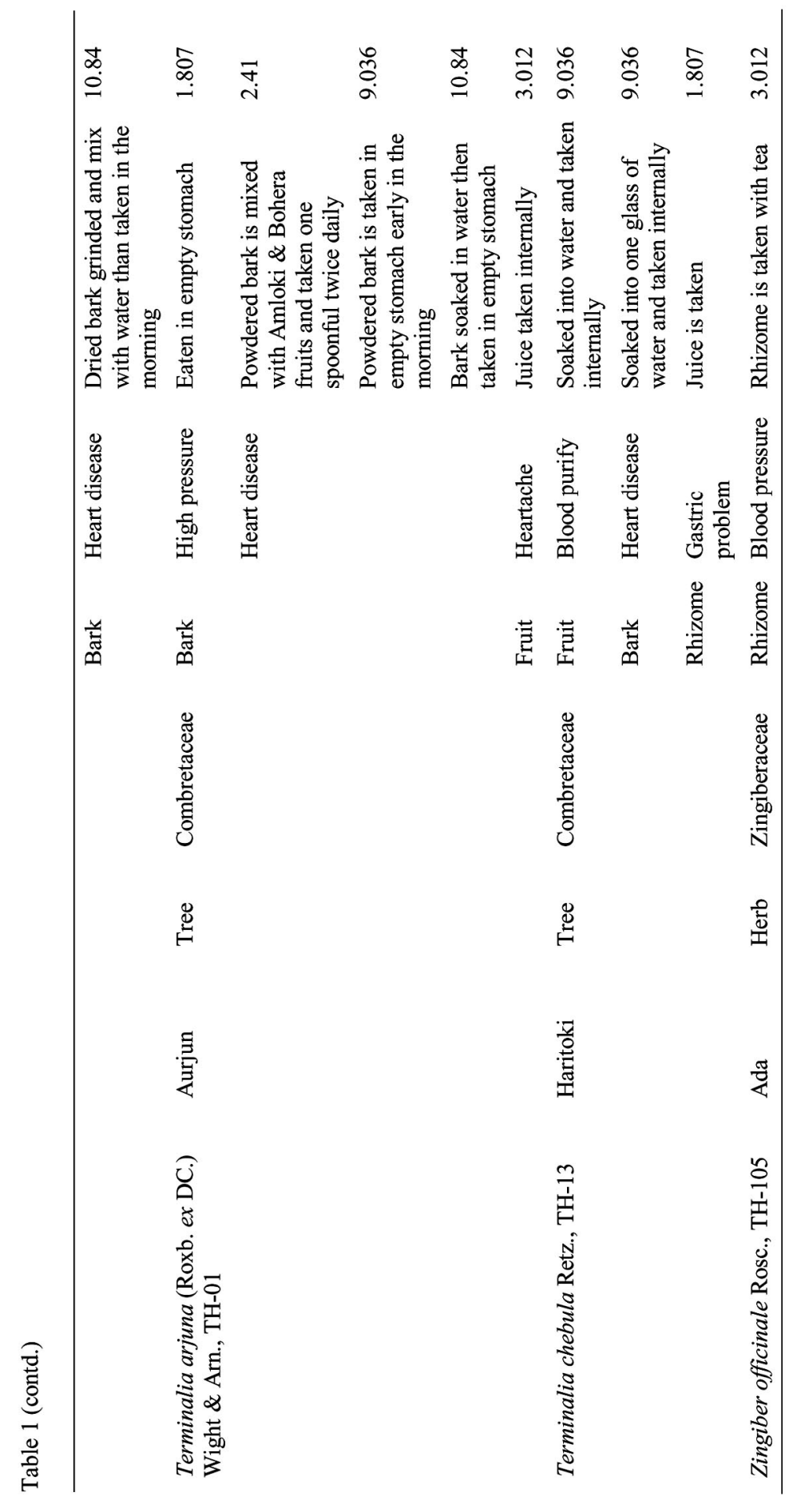




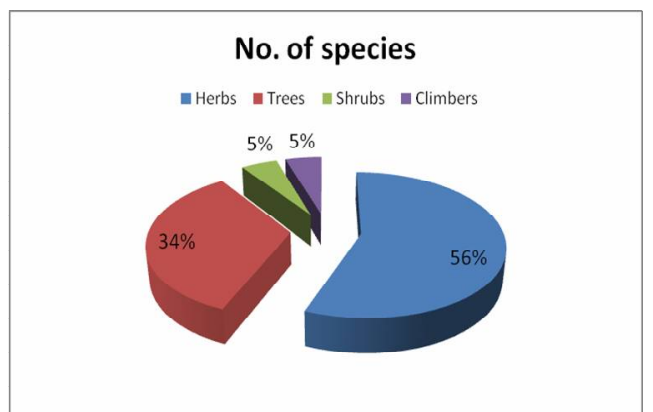

Fig.1. Habit diversity.

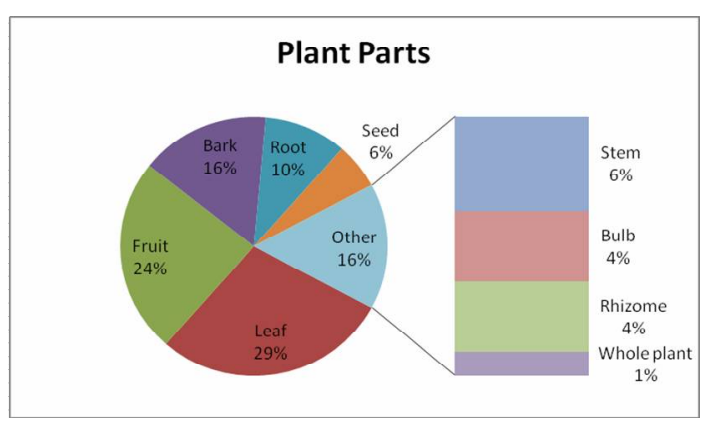

Fig. 2. Proportion of parts used of medicinal plant species.

Table 2. Factor of informant consensus (Fic) for each use category related to cardiovascular diseases.

\begin{tabular}{lccc}
\hline Category & $\begin{array}{c}\text { No. of species } \\
\text { (Ntaxa) }\end{array}$ & $\begin{array}{c}\text { No. of use reports } \\
\text { (Nur) }\end{array}$ & $\begin{array}{c}\text { Factor of informant } \\
\text { consensus (Fic) }\end{array}$ \\
\hline Antioxidant & 4 & 18 & 0.823529 \\
High blood pressure & 15 & 69 & 0.794118 \\
Heartache & 32 & 152 & 0.793333 \\
Blood purifier & 11 & 40 & 0.74359 \\
\hline
\end{tabular}

Table 3. Fidelity level (Fl \%) of most cited plant species.

\begin{tabular}{lccc}
\hline Scientific name & $\mathrm{Np}$ & $\mathrm{N}$ & $\mathrm{Fl} \%$ \\
\hline Achyranthes aspera L. & 5 & 5 & 100 \\
Terminalia bellirica (Gaertn.) Roxb. & 18 & 19 & 94.73 \\
Terminalia arjuna (Roxb. ex DC.) Wight \& Arn. & 42 & 45 & 93.33 \\
Terminalia chebula Retz. & 15 & 18 & 83.31 \\
Tamarindus indica L. & 33 & 38 & 86.84 \\
Rauvolfia serpentina Benth. & 14 & 18 & 77.78 \\
Alternanthera sessilis (L.) R. Br. ex Roem. \& Schult. & 11 & 15 & 73.33 \\
Allium sativum L. & 14 & 20 & 70 \\
\hline
\end{tabular}

$\mathrm{Np}=$ number of informants that claim a use of a plant species to treat a particular disease; $\mathrm{N}=$ number of informants that use the plants as a medicine to treat any given disease.

During ethnobotanical survey the data of the other use of these medicinal plants which showed highest frequency further calculated for Fidelity level (Table 3). Among the most cited ethnomedicinal plant species eight species showed above $70 \%$ Fidelity level (Table 3). Achyranthes aspera showed 100\% Fidelity level but with a low citation frequency (3.012) for the treatment of chest pain. In the present study Alternanthera sessilis was highly cited medicinal plant species for antioxidant category which scored highest Fic value. This plant is also used for the treatment of pox (Uddin et al., 2017), snake bite (Khan et al., 2002). In the present study Allium sativum (garlic) is used for the treatment of heart disease management. This plant is also used for gastric, cold, fever, chest pain, reduced pressure and ringworm (Uddin et al., 2015a,b, Uddin et al. 2017). Experimental and clinical studies showed that garlic produced hypertensive effects and also induced significant reduction in systolic and diastolic blood pressure. 
Terminalia aurjuna is used for the treatment of heartache which is also used for the same purpose reported from different area from Bangladesh (Uddin et al., 2012, Uddin and Hassan, 2014). This plant is also used for stomachache, cough, diabetes, menstruation, gastric pain, and dysentery (Uddin et al., 2006, 2012, 2017; Islam et al., 2014; Uddin et al., 2015a,b). Terminalia arjuna is a popular Indian medicinal plant with its bark been used for over centuries as cardiotonic. The bark has been found to contain several bioactive compounds including saponins and flavonoids (Navjot et al., 2014). The cardio protective effects, particularly of bark of Terminalia arjuna are well known. Such effects include reported protective effects of plant bark against doxorubicin induced cardio toxicity reported significant inotropic and hypotensive effect of bark, also increased coronary artery flow and protection of myocardium against ischemic damage (Sing et al. 2008, Dwivedi 2007).

Terminallia bellirica is used for the treatment of heart disease and also reported for stomachache, dysentery, appetizer, anemia, fever, bronchitis, constipation, asthma, vomiting, eye \& menstrual disorder (Uddin et al., 2006, 2012, 2014, 2015 and 2017). Tamarindus indica is used for reducing blood pressure which is also reported from others studies from Bangladesh (Uddin et al., 2015, 2017). Rauvolfia serpentina is used for controlling high blood pressure and also used for hypertension, mental disorder, stomach ache and gastric (Islam et al., 2014; Roy et al., 2008; Uddin et al., 2004). Tamarindus indica is reported for controlling high blood pressure. This plant is also reported for the treatment of reducing pressure, diarrhea, dysentery, appetizer, constipation, impotence, abscess and jaundice (Khan et al., 2002; Uddin et al., 2012, 2015, 2017). Different parts of plant affect the LDL oxidation and macrophage inflammatory response and also nephrotoxic effects and also having antipsychotic potential helpful in preventing delaying clot formation and have immunostimulant activity (Narendra and Khurana, 2018).

Compared with previous research (Ghani, 2003; Uddin et al., 2006, 2012, 2014, 2015, 2017; Haque et al. 2017; Sajib and Uddin, 2013; Uddin et al., 2013) Hylocereus undatus, Alternanthera paronychioides and Lactuca sativa seem to be newly reported medicinal plants for cardiovascular diseases treatment. Among the three plant species Lactuca sativa and Hylocereus undatus are not native to Bangladesh but local people used these plants for cardiovascular diseases.

The plant species with high citation, Fic and Fl values can be subjected to phytochemical investigation to find new class of active compounds for the treatment of cardiovascular diseases. The findings of the present study are very preliminary. Further long term studies are needed to validate the ethnomedicinal plants used by the local people for the prevention of cardiovascular diseases in Bangladesh.

\section{Acknowledgement}

The Authors are acknowledged to Bangladesh Centre for Advanced Studies and Research in Biological Sciences, University of Dhaka for partial financial support for the research. We are also thankful to the local people who helped us during data collections in the study areas.

\section{References}

Alam, M.K. 1992. Medical ethno $\square$ botany of the Marma tribe of Bangladesh. Economic Botany 46(3): 330330.

Alam, M.K., Choudhury, J. and Hassan, M.A. 1996. Some folk formularies from Bangladesh.Bangladesh J. Life Sci. 8(1): 49-63.

Alexiades, M.N., (ed.) 1996. Selected Guidelines for Ethno botanical Research: A Field Manual. The NewYork Botanical Garden, New York. 
Biswas, A., Bari M.A., Roy M. and Bhadra S.K. 2010. Inherited folk pharmaceutical knowledge of tribal people of Chittagong hill tracts, Bangladesh. Indian Journal of traditional Knowledge. 9(1): 77-89

Dwivedi, S. 2007. Terminalia arjuna Wight \& Arn. - A useful drug for cardiovascular disorders. Journal of Ethnopharmacology. 114: 114-129.

El-Saharty, Ahsan K.Z., Koehlmoos, Engelgau M.M. 2013. Tackling Non communicable Diseases in Bangladesh: Direstion in Development. Washington, DC: World Bank. License: Creative Commons Attribution CC BY 3.0. World Bank Publications. pp. 1-13.

Emily, S., Rahman M., Hossain M . J, Nahar N., Fazul M. A., Islam N., Sultana R., Akhtar S., Haider M. S., Islam M.S., Rahman M.W., Uddin M.Z., Mondal U.K. and Luby S.L. 2010. Fatal outbreak from consuming Xanthium strumarium seedlings during time of food scarcity in northeastern Bangladesh.PLoS ONE 5(3) |e9756.doi:10.1371/journal.pone.0009756.

Firedman, J., Yaniv, Z. Dafni, A. and Palewitch, D. 1986. A preliminary classification of healing potential plants, based on a rational analysis of an ethno pharmacological field survey among Bedouins in the Negev Desert, Israel. Journal of Ethno Pharmacology 16: 275-287.

Ghani, A. 2003. Medicinal plants of Bangladesh with chemical constituents and uses (2nd edition). Asiatic society of Bangladesh, Dhaka. pp. 1-603

Gowri, J,Vijay A.A., Achi R.S., Archunan G. , Kalavathy S., Sampath K.S. and Vijaya K.K. 2011. Redemptive benefit of atorvastatin in the risk factors of coronary artery disease. J. Pharm. Res. 4(3): 627-629.

Hassan, M.A. and Khan, M.S. 1986. Ethnobotanical record of Bangladesh-1: Plants used for healing fractured bones. J. Asiatic Soc. Bangladesh. (Sci.). 12 (1\&2): 33-39.

Hassan, M.A. and Khan, M.S. 1996. Ethnobotanical record of Bangladesh-2. Plants used for healing cuts and wounds. Bangladesh J. Plant Taxon. 3(2): 49-52.

Haque, M., Uddin M.Z., Hassan M.A. and Saha M.L. 2017. Plants used for the treatment of diabetes in Brahmanbaria, Bangladesh. Clinical and Experimental homoepathy 4(3): 8-18.

Haque, T, Uddin M. Z., Saha M.L., Mazid M.A. and Hassan M.A. 2014. Propagation, antibacterial activity and phytochemical properties of Litsea glutinosa (Lour.) C. B. Robinson Dhaka Univ. J. Biol. Sci. 23(2): 165-171.

Heinrich, M., Ankli, A., Frei, B. and Weimann, C. 1998. Medicinal plantsin Mexico: healers consensus and cultural importance. Social Science and Medicine 47: 1859-1871.

Hennekens, H.C. 2000. Clinical and research challenges in risk factors for cardiovascular diseases. Eur. Heart. J. 21: 1917-1921.

Hyland, B.P.M. 1972. A technique for collecting botanical specimens in rain forest. Flora Malesiana Bulletin 26: $2038-2040$

Islam, M.K., Saha S., Mahmud I., Awang K, Jamal Uddin S., Rahman M.M. and Shilpi J.A.M. 2014. An ethnobotanical study of medicinal plants used by tribal and native people of Madhupur forest area, Bangladesh. Journal of Ethnopharmacology 15: 921-93.

Joshi, P., Islam S., Pais P., Reddy S., Dorairaj P. and Kazmi K. 2007. Risk factors for early myocardial infarction in South Asians compared with individuals in other countries. JAMA. 297(3): 286-94.

Khan, M.S., Uddin M.Z. and Hassan M.A. 2002. Ethnobotanical survey in Rema $\square$ Kalenga wildlife sanctuary (Habiganj) in Bangladesh. Bangladesh J. Plant Taxon. 9(1): 51-60.

Krisela S. 2007. The heart and stroke foundation South Africa heart disease in South Africa Media data document.http://www.heartfoundation.co.za/docs/heartmonth/HeartDi seasein.SA.pdf.

Kumar, S., Joseph L., George M. and Sharma A. 2011. A review on anticoagulant / antithrombotic activity of natural plants used in traditional medicine. A review article 8(1): 70-74.

Lee, W. Yang E.J., Ku S.K., Song K.S. and Bae J.S. 2012. Anticoagulant activities of oleanolic acid via inhibition of tissue factor expressions. The Korean Society for Biochemistry and Molecular Biology. 18, April, pp. 390-395. 
Manicam, C., Abdullah1, J.O., Tohit, E.R.M., Seman, Z., Chin, S.C. and Hamid1, M. 2010. In vitro anticoagulant activities of Melastoma malabathricum Linn. aqueous leaf extract: A preliminary novel finding. Journal of Medicinal Plants Research 4(14): 1464-1472.

Mia, A. S. and Haque A. 1988. Ethnodiversity of medicinal plants used by Tripura community of Hazarikhil in Chittagong District of Bangladesh, Department of Botany, University of Chittagong, Chittagong 4331, Bangladesh, J. Taxon. Biodiv. Res. 5: 27-32.

Navjot, K., Nusrat S., Negi H., Pandey A., Reddy S., Harpreet K., Chadha N. and Samir M. 2014. Terminalia arjuna in Chronic Stable Angina: Systematic Review and Meta-Analysis. Cardiology Research and Practice Volume, Article ID 281483, 7 page. http://dx.doi.org/10.1155/2014/281483.

Narendra, K. and Khurana S.M.P. 2018. Phytochemistry and medicinal potential of the Terminalia bellirica Roxb. (Bahera). Indian Journal of Natural Products and Resources 9(2): 97-107.

Olorunnisola O.S., Bradley G. and Afolayan A. J. 2011. Ethnobotanical information on plants used for the management of cardiovascular diseases in Nkonkobe Municipality, South Africa. Journal of Medicinal Plants Research 5(17): 4256-4260.

Roy, S., Uddin M.Z. Hassan M.A. and Rahman M.M. 2008. Medicobotanical report on the Chakma people of Bangladesh .Bangladesh J. Plant Taxon. 15(1): 67-72.

Singh, G., Singh A.T., Abraham A., Bhat B., Mukherjee A. and Verma R. 2008. Protective effects of Terminalia arjuna against Doxorubicin-induced cardiotoxicity. Journal of Ethnopharmacology 117: $123-129$.

Sajib N.H. and Uddin S.B. 2013. Medico-Botanical Studies of Sandwip Island in Chittagong, Bangladesh. Bangladesh J. Plant Taxon. 20 (1): 39-49.

Trotter, R.T. and Logan M.H. 1986. Informant census: A new approach for identifying potentially effective medicinal plants. In: Etkin, L.N. (Ed.), Plants in indigenous medicine and diet. Redgrave, Bedford Hill, New York, pp. 91-112.

Uddin, M.Z. and Roy S. 2007. Collection and Management of Selected Medicinal Plants in Rema Kalenga Wildlife Sanctuary.In: Making Conservation Work: Linking rural livelihoods and protected area management in Bangladesh edited by Fox, J. Bushley, B.R., Dutta S. and Quazi, S.A. 2007. Monograph of East $\square$ West Center, Hawaii, USA. pp. 66-83.

Uddin, M.Z., Khan M.S. and Hassan M.A. 2001. Ethnomedical Plant records of Kalenga forest range (Habiganj), Bangaldesh for Malaria, Jaundice, Diarrhoea and Dysentery. Bangladesh J. Plant Taxon. 8(1): 101-104.

Uddin, M.Z., Hassan M.A. and Sultana M. 2006. Ethnobotanical survey of medicinal plants in PhulbariUpazila of Dinazpur district, Bangladesh. Bangladesh J. Plant Taxon. 12(1): 63-68.

Uddin M.Z., Hassan M.A., Rahman M.M. and Arefin M.K. 2012. Ethno-medico-botanical study in Lawachara National Park, Bangladesh. Bangladesh J. Bot. 41(1): 97-104.

Uddin M.Z. and Hassan M.A. 2014. Determination of informant consensus factor of ethnomedicinal plants used in kalenga forest, Bangladesh. Bangladesh J. Plant Taxon. 21(1): 83-91.

Uddin M.Z, .Hassan M.A. and Kibria M.G. 2015. Study of ethnomedicinal plants used by the local people of feni district, Bangladesh. Journal of Asiatic society, Sci. 41(2):203-223.

Uddin, M.Z., Arefin M.K., Alam M.F., Kibria M.G., Podder S.L. and Hassan M.A. 2017. Consensus of the people's healthcare knowledge in the use of ethno $\square$ medicinal plants in and around lawachara national park. Journal of Asiatic Society 43(1): 101-123.

Uddin, M.S., Chakma J.J., Alam K.M.M. and Uddin S.B. 2015a. Ethno-medico Studies on the Uses of Plant in the Chakma Community of Khagrachari District, Bangladesh. J. Med. Plants Stud. 3(1): 10-15.

Uddin, M.S., Chowdhury V., Uddin S.B., Mazumder A.A.M. and Howlader M.S.A. 2015b. Ethnobotanical Survey of Medicinal Plants Used By the Lushai Community in Bandarban District, Bangladesh. J. Advanced Botany and Zoology, V 2I4. DOI: 10.15297/JABZ.V2I4.04

Uddin, S.B. 2013. www.ebbd.info. Bangladesh Ethnobotany Online Database.

Uddin, S.N., Hassan M.A. and Rhaman M. 2004. Preliminary ethnomedical plant survey in Khagrachari district Bangladesh. Bangladesh J. Plant Taxon. 11(2): 39-48. 
WHO 2003. The World Health Report-2003. https://www.who.int/whr/2003/en/

Yosuf, S. 2006. Ethnobotanical investigation into the Mandi ethnic, Bangladesh J. Plant Taxon. 14(2): $129-145$.

Yusuf M, Begum J., Hoque M.N. and Chowdhury J.U. 2009. Medicinal plants of Bangladesh. BCSIR, Chittagong

Yusuf, M. and Uddin J. 2006. Ethno-medico-botanical knowledge from Kaukhali proper and Betbunia of Rangamati District, Bangladesh J. Plant Taxon. 13(1): 55-61.

(Manuscript received on 1 February, 2019; revised on 4 May, 2019) 